which lingers for a short time at the seat of inoculation and then rapldly spreads through the body. This organism transmitted from parent to child is the cause of Inherited syphills.

2. Many forms of arthritis formerly classed as syphillitic are due to other infective agents acting upon tiesues modified by the action of the syphilitic virus.

3. Syphilitic changes in the bones, joints, tongue, and other parts may occur as a result of inherited syphills much later in life than is usually recognized. They are then the result of accidental causes, and they are often the only evidence of the inherited taint.

4. The modern trestment of syphllis consists (a) In the more carefal administration of mercury, which is now given to cure the disease 1tself, and not merely to relleve the symptoms as has hitherto been the case; (b) In a recognition of the limitations of the absorptive power of the lodides; $(c)$ In a freer use of surglcal methods to remove the products of agphilltic inflammation before the lodides are admlnlstered.

\section{A CASE OF OCHRONOSIS.}

$$
\begin{aligned}
& \text { I, O. E. HARSTON, and A. B. BOLTAU, } \\
& \text { F.R.C.8.ED., } \\
& \text { HON. SURGEON, KINGSBRIDGE PHYSICIAN, SOUTH DEVON AND } \\
& \text { COTTAGE HOSPITAL, } \\
& \text { BAST CORNWALL HOSPITAL, } \\
& \text { PLYMOUTH, ETC. }
\end{aligned}
$$

THE case which is the subject of this communlcztion seems worthy of being placed on record, owing to the unusual features which it presents and the absence of any discoverable canse of the abnormal pigmentation whlch is to be descrlbed.

J. A., a farmer, aged 60 History.

aged 60 , first csme under observation in October, 19J7. He complained of an increasing discoloration of the akin of the face, which ho had first noticed early in that month, and which was then suffiolently marked to osuse comment amongs his friends and in the streets. His prevlous heislth had been entirely good, and may be dismiseed without comment beyond the statement that in the month of September be had suffered from "eczems" of the chest. This was apparently nothing more than a "fiannel ragh" for which he was treated by a ohemist. The latter, as we found on invastiwas treated by a ohemist. The latter, as we found on invastiwas applied to the chest bat not to any other part of the body.

Condition on Examination.

He was a healthy-looking msn, well nourished, and somewhst Inclined to stoutness: The colour of the skln of the face was a slats bloe, whlch, orer the malar eminonoes where was firat not less pigmented area the skin could be seen to be thlokly sown with minute patches of deep brown plgment, less then half a millimetre in diameter. The pigmentation extended backwards as far 89 the ears, wbich were both discoloured, the helices especially being of a dark.blue tint. Ths patient being bearded, the skin of the jaw was not so easy to exsmine, bat appirently it was not pigmented. In fact the pigmentation was confined to those parts of the face which were exposed to who the brim, and la those areas protected by the growth of hair. Tition ditlon common 10 men living in the open sir, but there was
no abnormal discoloration. The skln over the trank was also free from excess of pigment, but over the abdomen, ohest, and bsok were sosttered numerous black warts. These the patient sold he had hed all his life, and, as far as he could tell, not one of them had recently altered in size or given him any pain. A carefal examination of them did not disolose anj evidence of nlceration, Irritation, or growth, nor were sny of the superfiolal lymphstio glands enlarged or tender. The mucous memficisl lymphatio glands enlarged or tender. The mucous memof the herd palate, jast in front of lts janction with the soft of the hard palate, jast in front of lts janction with the soft palate, there was a small, round, blulsh patch about 1 mm. In external to the cornes, there was a slight brownish discoloration. The fundi oculoram were normal, bojond a little excess of pigment round the discs.

The urine was repeatedly examined, but nothlng abnormal was found. Its speclfio graviti' was 1020, the colour a pale mber and it contained no albumen or anste.

All his organs appeared normal, there being no evidence of disesse in anj of them.

The diagnosis will best be consldered by discussing the various possible causes for such a condition.

It - Is not a case of vascular dilatation and turgescence, sirice the coloration is permanent and cannot be lessened or removed by pressure. : It must be remarked; however, that exposure to cold canees a deeper coloration, superImposing a vascular congestion on the plgmentation Nelther is it a case of cyanosis, for the same reasons, and from the fact that the mucous 'membranes preserve thelr normal colour.

This seemed a possible cause, and diligent search was made to discover a primary melanotic growth. As stated, there were numerons plgmented warts on the skin, but they all seemed to be quilescent. - Rectal examination revealed nothing, nor was there any history of blood belng psssed with the stools, nor of any rectal pain. The eyes also, so often the seat of such a primary growth, were quite healthy. Moreover, in the event of 1 ts being melanosis, it would be expected that the urine would contain melanin, but there was no hlstory of darkcoloured urine ever having been passed, nor of its baving darkened after being voided. The addition of oxldizing agents to the urlne caused no darkening, as would have been the case had melanogen been present. Farther, the patlent's general good health, the absence of any jymphatic enlargement, and the fact that he maintained his body weight, all seemed to negative this diagnosis.

Metallic Poisoning.

The long-contlnued use of certain metals, notably sllver, argenlc, and lead, have often led to a permanent pigmentation of the skin. Inquiry was therefore made into the patient's history, to ascertaln whether he had been in the hablt of using preparations of any of these metals, either industrially or medicinally, but without result. Even in his tarm duties he had not been brought into contact with them. Special attention was paid to the question of sheep-dipping, as many of the preparatlons used for this purpose contain argenic, bat it appeared that he had not had anything to do personally with this work. The olntment prescribed by the chemist was a simple mercurial preparation, and the small quantity (less than half an ounce) used was obviously not to blame.

As far as possible, therefore, the question of metallic polsoning has been excluded. On the other hand, the plgmentary distribution, in the parts of the skin exposed to the weather, corresponds with that seen in argyria.

\section{Ochronosis.}

From the description of the case it will be seen that it corresponds very closely with those rare cases whlch have been described under this title. A case was fully reported by F. M. Pope in the Lancet of January 6th, 1906; and in the Quxrterly Journal of Medicine for January, 1908, Professor Osier and other writers critically review all the recorded cases, and describe a new case, supplying also a complete blbllography.

The association of ochronosis with alcsptonurla is still undetermined. In our case there was at no time any evidence of the presence of alcapton in the urine. The urine did not contaln a reducing agent. nor did it darken on 'the addition of oxidizing agents. Further, there was nothing in the patient's history to indicate that he had been exposed to the possibllity of polsoning with carbolic acid, which is occasionally the precursor of alcaptonuria. He had not used any carbolic preparations since the prevlous lambing season-that is, a clear six months previously, and then only to a small extent in the weak solution of one ounce in a pint of oll as a lubricant.

In the case of ochronosis recorded in the Quarterly Jourmal of Medicine there was a clear hlstory obtainable of the nse of carbollc acld in the Immediate period belore the appearance of the plgmentation. Other cases, however, have not given this historg.

For the present we are Inclined to classify this case as one of ochronosis, and the chronicity would favour this view, for at the time of writlng, slx months after its first appearance, the plgmentation - is, it anything, more pronounced than when first seen in October.

Tre late Mr. Caleb Ashworth Tate, of West Dulwich, whose will has recently been proved, bequeathed $£ 5,000$ each to the National Hospital for the Paralysed and Epileptic and the National Society for the Employment of Epileptics... He also left sums of $£ 1,000$ each to the Surgical Aid Society and the Britioh Home for Incurables, Streatham. 